\title{
Coprophagy of African Wild Dog faeces by Hooded Vultures in Botswana
}

\author{
Richard P. Reading ${ }^{1,2}$, Botilo Tshimologo ${ }^{2,3}$, and Glyn Maude ${ }^{1,4}$
}
${ }^{1}$ Raptors Botswana, Maun, Botswana
${ }^{2}$ Okavango Research Institute, University of Botswana, Maun, Botswana
${ }^{3}$ BirdLife Botswana, Gaborone, Botswana
${ }^{4}$ Department of Research \& Conservation, Denver Zoological Foundation, Denver, CO, USA

*Corresponding author: rpreading@gmail.com

http://dx.doi.org/10.4314/vulnew.v71i1.5

Coprophagy by vertebrates is rare, especially among birds and species that consume the faeces of other species (Soave \& Brand 1991, Hirakawa 2001, Shimada 2012). While New World Vultures practice coprophagy (Del Hoyo et al. 1994, Buckley 1999, Blanco et al. 2013), the only Old World vulture we could find that consumes faeces is the Egyptian Vulture (Neophron percnopterus) (Negro et al. 2002, Hidalgo et al. 2009). Egyptian Vultures feed on the faeces of ungulates, apparently to obtain carotene (Negro et al. 2002), while New World vultures apparently are searching for undigested prey or nutrients that have difficulty obtaining elsewhere (Del Hoyo et al. 1994, Buckley 1999, Blanco et al. 2013). Other species practice coprophagy to obtain iron, B12, fatty acids, protein, rare nutrients (Soave and Brand 1991).

While tracking African wild dogs (Lycaon pictus) as part of a behavioural study in the Okavango Delta region of Botswana, we observed coprophagy behaviour by Hooded Vultures (Necrosyrtes monachus). Hooded Vultures often accompanied wild dogs in northern Botswana. In March, 2010, while with a pack of dogs that had recently killed a male Greater Kudu (Tragelaphus strepsiceros), we observed several Hooded Vultures. While the dogs rested near the kill, the vultures picked at scraps of the carcass and followed the dogs to quickly consume their faeces, including liquid stool, whenever the dogs vacated (Figures 1 - 3). 


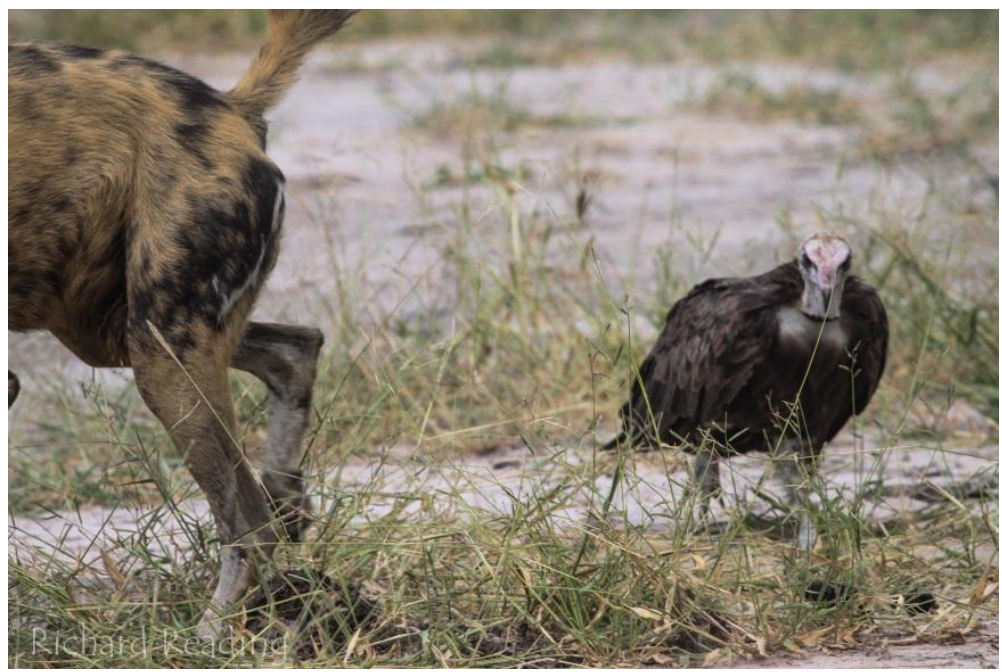

Figure 1: Hooded Vultures (Necrosyrtes monachus) watching and following an African wild dog (Lycaon pictus) as it defecates in the Okavango Delta, Botswana.

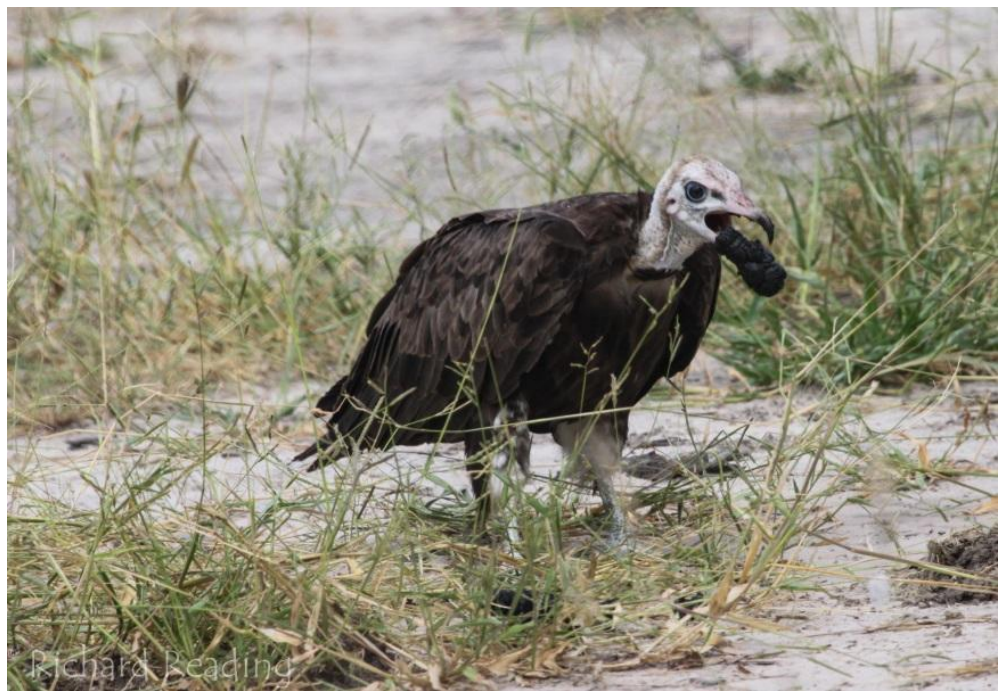

Figure 2: Hooded Vulture (Necrosyrtes monachus) consuming African wild dog (Lycaon pictus) faeces in the Okavango Delta, Botswana 


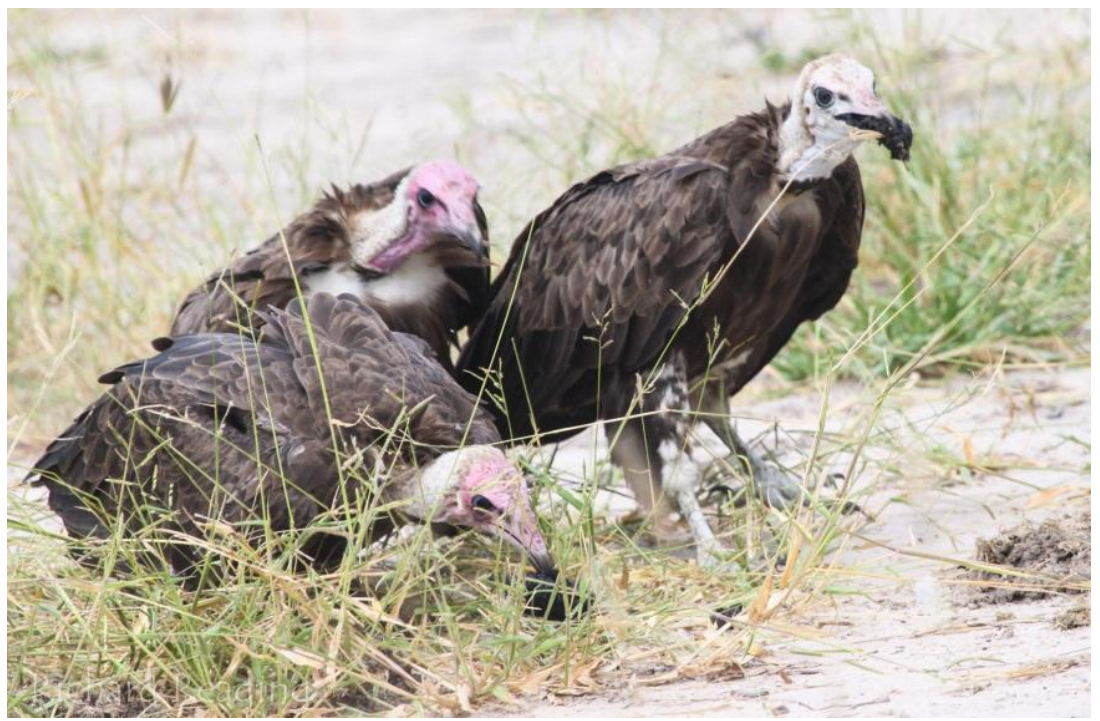

Figure 3: Hooded Vultures (Necrosyrtes monachus) consuming African wild dog (Lycaon pictus) faeces in the Okavango Delta, Botswana

Other researchers report that Hooded Vultures follow wild dogs, but none report on coprophagy (Squires 2005, Steyn 2005). Although safari guides and wild dog researchers appear to know about coprophagy behaviour, we could not find it documented in the literature. We hypothesize that Hooded Vultures obtain undigested nutrients from the consuming wild dog faeces, although they may well be obtaining rare nutrients as well or instead. If vultures practice coprophagy primarily for nutrition, African wild dogs provide Hooded Vultures with food from their kills and their faeces.

\section{Acknowledgments}

Support provided by Denver Zoological Foundation, Wildlife Wilderness Trust, and Kalahari Research and Conservation. 


\section{References}

Blanco, G, Hornero-Méndez, D., Lambertucci, S.A., Bautista, L.M.,

Wiemeyer, G., Sanchez-Zapata, J.A., Garrido-Fernández, J., Hiraldo, F., \& Donázar, J.A. 2013 Need and Seek for Dietary Micronutrients:

Endogenous Regulation, External Signalling and Food Sources of Carotenoids in New World Vultures. PLOS ONE 8(6): e65562.

Buckley, N.J. 1999. Black Vulture (Coragyps atratus). In: Poole A. (Ed.). The Birds of North America Online. Ithaca: Cornell Lab of Ornithology. http://bna.birds.cornell.edu/bna/species/411. doi:10.2173/bna.411

Del Hoyo, J., Elliot, A. \&Sargatal, J. 1994. Handbook of the birds of the world, vol. 2: New World vultures to guineafowl. Barcelona: Lynx Edicions.

Fenolio, D. B., Graening, G.O., Collier, B.A. \&Stout, J.F. 2006. Coprophagy in a cave-adapted salamander; the importance of bat guano examined through nutritional and stable isotope analyses. Proceedings of the Royal Society $B$ Biological Sciences 273(1585): 439-444.

Hidalgo, S., Zabala, J., Zuberogoitia, I., Askona, A. \& Castillo, I. 2009. Food of the Egyptian Vulture (Neophron percnopterus). Buteo 14: 23-29.

Negro, J.J., Grande, J. M., Tella, J.L., Garrido, J., Hornero, D., Donázar, J.A., Sanchez-Zapata, J.A., BenÍtez, J.R. \& Barcell, M. 2002. Coprophagy: An unusual source of essential carotenoids. Nature 416: 807-808.

Shimada, T. 2012. Ducks foraging on swan faeces. Waterfowl 62: 224-227.

Soave, O. \& Brand, C.D. 1991 Coprophagy in animals: A review. The Cornell Veterinarian 81 (4): 357-364.

Squires, N. 2005. Hooded Vulture follows wild dogs. Vulture News 52: 38.

Steyn, P. 2005. Hooded Vultures following wild dogs. Vulture News 53: 30. 